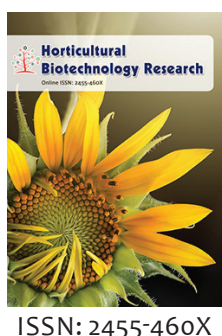

Received: October 07, 2021 Revised: January 10, 2022 Accepted: January 11, 2022 Published: February 25, 2022

*Corresponding Author: Taufiqur Rahman Sarkar Email: nayonbot@yahoo.com

\section{Direct in vitro organogenesis from leaf and internode of Coccinia cordifolia (L.) Cogn.}

\author{
Md. Taufiqur Rahman Sarkari*, Md. Mizanur Rahman², Mohammad Firoz Alam² \\ ${ }^{1}$ Department of Botany, Joypurhat Government College, Joypurhat, Bangladesh, ${ }^{2}$ Department of Botany, University \\ of Rajshahi, Bangladesh
}

\begin{abstract}
The current study was carried out to elucidate a reproducible protocol to develop plants directly from leaf and internodes to facilitate the genetic transformation in Coccinia cordifolia (L.) Cogn., a medicinal plant of the cucurbitaceae family. In vitro grown leaf and internodes were used, which were collected for regenerated shoots from field-grown nodal segments that were sterilized by $0.1 \% \mathrm{HgCl}_{2}$ treatment for 6 minutes. The nodal segment cultured on BAP, Kn and BAP, NAA combination where $1.5 \mathrm{mg} / \mathrm{L}$ BAP solitary supplement and augmented supplement with $0.1 \mathrm{mg} / \mathrm{L} \mathrm{NAA}$ was most effective as $80 \%$ shoots regenerated with $4.0 \pm 0.37$ and $2.7 \pm 0.45$ shoots per culture, respectively. Collected leaf and internode responded $90 \%$ at $1.5 \mathrm{mg} / \mathrm{L} \mathrm{BAP}+0.1 \mathrm{mg} / \mathrm{L} \mathrm{NAA}$ fortified full-strength MS medium. The highest number of shoots also regenerated in the same combination which were $8.1 \pm 0.30$ and $10.2 \pm 0.40$, respectively and found internode as the best explant for direct organogenesis. For root induction, half strength of MS medium supplemented with $0.1 \mathrm{mg} / \mathrm{L} \mathrm{IBA}$ was found most effective. The highest number of roots regenerated per shoot $(6.8 \pm 0.10)$ and root length $(2.8 \pm 0.20)$. The successful acclimatization of the in vitro $(80 \%)$ grown plantlets proved the validity of the developed protocol of using biotechnological techniques for improving the plant.
\end{abstract}

KEYWORDS: Direct organogenesis, adventitious shoots, leaf, internode, plant growth regulators

\section{INTRODUCTION}

Organogenesis is the formation of adventitious shoots (callogenesis), roots (rhizogenensis) from the cells in a rigidly controlled culture medium with exogenous hormone. This technique is generally achieved by developing meristemoids (a group of meristematic cells) that initiate primordium formation. Organogenesis might be indirectly where explant is used to form callus prior to adventitious shoot and root formation and directly where adventitious shoots or roots induce directly from explants like leaf, petiole, internode, cotyledon, hypocotyl, etc. (Brown and Thorpe, 1986). Organogenesis adapted to develop a new variety with new characteristics of medicinal or agronomical value through the genetic transformation which impede during axillary shoot proliferation (Pal et al., 2007; Corredoira et al., 2008; Alam et al., 2010a). However, shoot regeneration from callus is not preferable as it causes the loss of plantlets identity in an uncontrolled manner from mother plants (Alam et al., 2019). Therefore, direct organogenesis is most preferable to produce mass propagation with true-to-type strains and also facilitates genetic transformation with minimal possibilities of somaclonal variation or alteration of the target plant genome in the propagated plantlets (Shibli \& Smith, 1996; Verma et al.,
2021). Direct organogenesis also diversifies the plants' genetic constituents in contrast to micropropagation which declines the genetic diversity (Yang et al., 2012).

The medicinal plant, Cocconia cordifolia (L.) Cogn., has been traditionally utilized against joint paint, arthritis, skin disease, ulcer, acidity, gastric, asthma, urinary tract infection, diabetes (Zakaria et al., 2011; Girish et al., 2011; Pekamwar et al., 2013). The plant, therefore, gained a lot of attention in the pharmaceutical industry for its phytochemical contents e.g., phenols, tannins, saponins, terpenoids, flavonoids, arabinose, xylose, mannose, galactose, glucose, and rhamnose, which showed activity as antidiabetic, antioxidants, antimicrobial, anti-inflammatory, antipyretic, anticancer, autoimmune treatment, anti-hepatotoxicity (Ramachandran et al., 2014). Because of its high medicinal potency against diabetes, the plant is reckoned as a "substitute for insulin" (Borah et al., 2019).

This highly pharmacological valuable plant belongs to the Cucurbitaceae family with having tuberous root, soft stem with heart or pentagon-shaped leaves of alternative phyllotaxy, and white coloured flower that form fruits with seed (Hussain et al., 2011; Pekamwar et al., 2013). Coccinia cordifolia (L.) Cogn.,

Copyright: (-) The authors. This article is open access and licensed under the terms of the Creative Commons Attribution License (http://creativecommons.org/licenses/by/4.0/) which permits unrestricted, use, distribution and reproduction in any medium, or format for any purpose, even commercially provided the work is properly cited. Attribution - You must give appropriate credit, provide a link to the license, and indicate if changes were made. 
is generally a perennial climbing herb that naturally a seed germinating plants despite of having a slow seed setting and germination rate because of a thin nuclear membrane in seed that cause of impermeability to water and gaseous substance (Sundari et al., 2011). This reason is responsible for the plant to cope with high commercial demand for the pharmaceutical industry as "sugar and fat balance", a nutritional supplements produce from the plant (Kashem \& Rahman, 2018). Various in vitro regeneration techniques are practiced for the improvement of medicinal plants to produce uniform plants as well as variant for breeding purposes (Alam et al., 2010b; Sharmin et al., 2013). Therefore, C. cordifolia (L.) Cogn., like many other Cucurbitaceae species, has been multiplied by axillary shoot regeneration and callus derived adventitious shoot proliferation from node, internode, and leaf (Sarker et al., 2009; Sundari et al., 2011 ; Patel \& Ishnava, 2015; Kashem \& Rahman, 2018; Borah et al., 2019). However, there is no report of direct organogenesis for the plant leaves and internodes. Hence, the present study was undertaken to develop an efficient reproducible shoot initiation method through direct organogenesis from leaf and internode to subsequently facilitate the genetic transformation and strengthen the biodiversity conservation and utilization of the plant resources through germplasm preservation.

\section{MATERIALS AND METHODS}

\section{Explants Collection}

Mature plants were collected from a fallow land of University of Rajshahi and immature nodal segments were inoculated for axillary shoot regeneration. Then from in vitro grown leaf and internode of 0.5-1 cm were excised for direct adventitious shoot proliferation.

\section{Medium Preparation and Sterilization}

Stock solutions of micro and minor elements, vitamins, plant growth regulators were prepared in a distinct conical flask with required quantities and stored at $4^{\circ} \mathrm{C}$ refrigerator. An adequate amounts of all the nutrients, vitamins, growth regulators were poured into a beaker to prepare $1000 \mathrm{ml}$ of MS (Murashige and Skoog) medium (Murashige and Skoog, 1962). Additional distilled water was added to mark up the volume of $1 \mathrm{~L}$ after dissolving $3 \%(\mathrm{w} / \mathrm{v})$ sugar as carbohydrate for a carbon source. The $\mathrm{pH}$ was then adjusted at $5.7 \pm 0.1$ with a digital $\mathrm{pH}$ meter by adding $0.1 \mathrm{~N} \mathrm{NaOH}$ or $0.1 \mathrm{~N} \mathrm{HCl}$. After that, $0.75 \%$ $(\mathrm{w} / \mathrm{v})$ agar was added to solidify the medium and heated in a microwave for 5 minutes, and finally, the medium was sterilized by autoclaving for 20 minutes at $121^{\circ} \mathrm{C}$ temperature and 1 atmospheric pressure.

Field collected samples were sterilized with savlon and tween20 for 2-3 times with distilled water in a conical flask after rinsing under running tap water to eliminate surface dust and contaminants. Then $0.1 \% \mathrm{HgCl}_{2}$ treatment for $5-8$ minutes before washing with sterile distilled water for 3-5 times were applied for the surface sterilization of nodal segments in a laminar air-flow cabinet.

\section{Direct Shoot Regeneration}

Nodal segments were cultured in semisolid MS medium supplemented with $0.5,1.0$, and 1.5 of BAP or $\mathrm{Kn}$ or 0.5 and $1.5 \mathrm{mg} / \mathrm{L}$ BAP combine with $0.1,0.2$, and $0.5 \mathrm{mg} / \mathrm{L} \mathrm{NAA} \mathrm{for}$ axillary shoot development. In vitro grown shoots were then collected and leaf parts and internodes were cut in length of $0.5-1 \mathrm{~cm}$ in a laminar air flow cabinet and transferred into MS medium containing $1.0,1.5$, and $2.0 \mathrm{mg} / \mathrm{L}$ BAP individually or in combine with $0.1,0.2$, and $0.5 \mathrm{mg} / \mathrm{L}$ NAA, IBA, IAA, and 2,4-D for adventitious shoot regeneration.

\section{Rooting \& Acclimatization}

Leaf and internode generated shoots were detruncated in a single shoot and cultured in half-strength MS medium supplemented with 0.1 and $0.5 \mathrm{mg} / \mathrm{L}$ either of NAA, IBA, or IAA. All the in vitro experiments were kept in a growth chamber established with a light intensity of 2000-3000 lux to maintain a 16 hours photoperiod and the temperature was controlled at $25 \pm 2{ }^{\circ} \mathrm{C}$. The rooted plantlets were then transplanted in a thumb pot containing sun sterilized sand and soil mixed with humus in the ratio of $1: 2: 1$. The potted plants were then acclimatized regularly in an ex vitro environment after being kept for 15 days in the growth chamber.

\section{Data Analysis}

Data were recorded after 5 weeks of cultivation for 7 replication in each experiment with 3 repetitions. Microsoft Excel was used to calculate the average value and standard error of the obtained data.

\section{RESULTS}

\section{Axillary Shoot Regeneration for Explant Selection}

For direct organogenesis in vitro grown leaf and internode was used from axillary shoots, regenerated through nodal segments of field collected plants. The collected plants were washed with antiseptic and cut into pieces with $4-6 \mathrm{~cm}$ before sterilization in a laminar airflow chamber with $0.1 \% \mathrm{HgCl}_{2}$ treatment for 5-8 minutes. Surface sterilant treatment for 6 minutes was found effective as almost $90 \%$ of explants survive and develop axillary shoots.

Axillary shoots were proliferated in full strength MS medium supplemented with either BAP, Kn, or NAA combination with BAP (Table 1). Among all the concentrations and combinations, $1.5 \mathrm{mg} / \mathrm{L}$ BAP found most profound medium as $80 \%$ shoots regenerated with $4.0 \pm 0.37$ shoots per culture, albeit the length of shoot $(4.2 \pm 0.22 \mathrm{~cm})$ was surpassed by $5.4 \pm 0.32 \mathrm{~cm}$ and $4.7 \pm 0.31 \mathrm{~cm}$ obtained at MS with $1.5 \mathrm{mg} / \mathrm{L}$ BAP with the addition of $0.1 \mathrm{mg} / \mathrm{L}$ and $0.2 \mathrm{mg} / \mathrm{L} \mathrm{NAA}$, respectively. However, the shoot number is relatively low in that two combinations. The lowest BAP and Kn concentration $(0.5 \mathrm{mg} / \mathrm{L})$ respectively showed minimum response rate $(50 \%$ and $40 \%)$ with minimal shoots number $(2.3 \pm 0.16$ and $1.8 \pm 0.55)$ and length 
Table 1: Effect of different concentration of cytokinin in MS medium on shoot proliferation from the nodal segments of field grown plants

\begin{tabular}{|c|c|c|c|c|c|}
\hline Types of cytokinin & $\begin{array}{l}\text { Different nutrient } \\
\text { media }\end{array}$ & $\begin{array}{l}\text { Response of } \\
\text { explants (\%) }\end{array}$ & $\begin{array}{l}\text { No. of total shoots per } \\
\text { culture }(\bar{X} \pm \text { S.E. })\end{array}$ & $\begin{array}{c}\text { Length of the } \\
\text { shoot }(\mathrm{cm})(\bar{X} \pm S . E .)\end{array}$ & $\begin{array}{c}\text { Basal callus } \\
\text { formation }\end{array}$ \\
\hline \multirow[t]{3}{*}{ BAP } & 0.5 & 50 & $2.3 \pm 0.16$ & $3.5 \pm 0.33$ & - \\
\hline & 1.5 & 80 & $4.0 \pm 0.37$ & $4.2 \pm 0.22$ & ++ \\
\hline & 2.5 & 70 & $3.9 \pm 0.51$ & $4.2 \pm 0.10$ & ++ \\
\hline \multirow[t]{3}{*}{$\mathrm{Kn}$} & 0.5 & 40 & $1.8 \pm 0.55$ & $3.1 \pm 0.35$ & - \\
\hline & 1.5 & 75 & $3.5 \pm 0.10$ & $4.0 \pm 0.35$ & ++ \\
\hline & 2.5 & 65 & $3.5 \pm 0.19$ & $4.2 \pm 0.52$ & ++ \\
\hline \multirow[t]{6}{*}{$B A P+N A A$} & $0.5+0.1$ & 60 & $1.7 \pm 0.16$ & $4.2 \pm 0.11$ & - \\
\hline & $0.5+0.2$ & 40 & $1.2 \pm 0.17$ & $3.4 \pm 0.25$ & + \\
\hline & $0.5+0.5$ & - & - & - & +++ \\
\hline & $1.5+0.1$ & 80 & $2.6 \pm 0.45$ & $5.4 \pm 0.32$ & + \\
\hline & $1.5+0.2$ & 65 & $2.0 \pm 0.55$ & $4.7 \pm 0.31$ & ++ \\
\hline & $1.5+0.5$ & 40 & $1.8 \pm 0.37$ & $3.2 \pm 0.10$ & ++ \\
\hline
\end{tabular}

(-) represents no response; $(+)$ indicates minor callusing; $(++)$ represents noticeable callusing; $(+++)$ represents abundant callusing

$(3.5 \pm 0.33 \mathrm{~cm}$ and $3.1 \pm 0.35 \mathrm{~cm})$, but no callus formation was observed, which was recorded with additional $0.1 \mathrm{mg} / \mathrm{L}$ NAA. Additional NAA with BAP provided callus formation at the bottom of the nodal segment.

\section{Direct Organogenesis}

Adventitious regeneration was established using sole BAP in MS medium and coupled BAP with 4 types of auxin through direct organogenesis from leaf and internode. Inoculated explant in only BAP contain medium despite producing any shoots, little callus formed at the cut margin region while $2.0 \mathrm{mg} / \mathrm{L} \mathrm{BAP}$ coupled with $0.2 \mathrm{mg} / \mathrm{L}$ and $0.5 \mathrm{mg} / \mathrm{L}$ IBA, IAA, and 2,4-D in culture medium formed callus almost three times higher than the previous mentioned PGR (Table 2). Between the two in vitro grown explants, the internode segment possessed the highest regeneration rate with the highest shoot number and for hormonal combination, $1.5 \mathrm{mg} / \mathrm{L}$ BAP with $0.1 \mathrm{mg} / \mathrm{L} \mathrm{NAA}$ produced respectively, $8.1 \pm 0.30$ and $10.20 \pm 0.40$ no. of shoots for both leaf and internode explant with with $90 \%$ response rate (Figure la-d). Among BAP - IBA hormone combinations, the maximum frequency of $75 \%$ and $70 \%$, respectively, leaf and internode explants showed shoot buds formation at $1.5 \mathrm{mg} / \mathrm{L} \mathrm{BAP}$ with $0.1 \mathrm{mg} / \mathrm{L}$ IBA. This combination also produced $6.1 \pm 0.80$ and $4.3 \pm 0.10$ shoots per culture, respectively. On the other hand, BAPIAA, a maximum frequency of $60 \%$ and of $50 \%$ explants showed shoot buds differentiation at $1.5 \mathrm{mg} / \mathrm{L}$ BAP with $0.1 \mathrm{mg} / \mathrm{L}$ IAA having a maximum number of shoots $(4.6 \pm 0.40$ and $3.6 \pm 0.17)$ per culture, respectively for leaf and internode. And $1.5 \mathrm{mg} / \mathrm{L}$ BAP and $0.1 \mathrm{mg} / \mathrm{L} 2$ 2, 4-D showed maximum $50 \%$ and $45 \%$ bud formation from leaf and internode explants, respectively, which are much lower than other hormonal combination (Figure 1).

\section{In vitro Rooting and Hardening}

Adventitious shoots were excised into $2.5-3 \mathrm{~cm}$ and cultured into hormone omitted nutrient medium and $0.1,0.2 \mathrm{mg} / \mathrm{L}$ either of IBA, IAA or NAA mediated full and half strength MS medium (Table 3). Half strength MS medium regenerated the highest percentage of roots in almost every PGR concentration while $0.1 \mathrm{mg} / \mathrm{L} \mathrm{IBA}$ possessed the maximum number of roots $6.2 \pm 0.37$ and $6.8 \pm 0.10$ in full-strength and half-strength nutrients, respectively. Highest response rate of $95 \%$ was also observed at the lowest IBA concentration (Figure le). For the other two auxins, similar observation was also recorded, although the root number and root length were lower than IBA and $0.2 \mathrm{mg} / \mathrm{L}$ concentrated medium for every auxin showed lower response rate and lower morphological attributes with moderate callus at the root initiated region. However, $60 \%$ and $70 \%$ shoots develop roots without any callus in control full-strength and half-strength MS medium by producing $4.2 \pm 0.70$ and $5.2 \pm 0.50$ number of roots with $2.3 \pm 0.40 \mathrm{~cm}$ and $2.5 \pm 0.10 \mathrm{~cm}$ root length, respectively.

Well-developed rooted plantlets were transferred into a thumb pot containing sand: garden soil: organic fertilizer (1:2:1) for hardening. The hardening process was applied for 3 weeks in growth room with a plastic cover on the pots to create a greenhouse condition. The plants acclimatized to the ex vitro environment with $80 \%$ survival rate after a month.

\section{DISCUSSION}

Direct organogenesis regenerates plantlets from leaf or internode, bypassing the callus formation. This organogenic technique is highly applicable for the large scale of plantlet production as proliferated shoot number is higher than axillary shoot, and also somaclonal variation can be avoided, which can be possible in case of dedifferentiation (callus formation) and redifferentiation (shoot from callus) (kone et al., 2013). However, genotype determines the organgenic response in Cucurbitaceae species, phytohormone also responsible for the shoot morphogenesis (Shasthree et al., 2014).

Direct organogenesis for C. cordifolia (L.) Cogn. propagation is achievable as meristematic tissue potentialities to form new shoots and to utilize lower concentrations of plant growth regulators in the culture media. However, the requirement for exogenous auxin and cytokinin in the direct shoot regeneration process varies with the tissue system of the explants, apparently depending on the endogenous levels of the hormones in the tissue (Josekutty et al., 1993). The source of explant also determines the quality of the methodology as using in vitro grown leaves and internodes possess an abundant supply of 
Table 2: Effect of different concentrations and combinations of plant growth regulators in MS medium on direct shoot organogenesis from leaf explants of in vitro shoots

\begin{tabular}{|c|c|c|c|c|}
\hline Growth regulators (mg/L) & Explant types & $\begin{array}{c}\text { Frequency of } \\
\text { Regeneration (\%) }\end{array}$ & $\begin{array}{l}\text { No. of total shoots per } \\
\text { culture }(\bar{X} \pm \text { S.E. })\end{array}$ & Basal callus formation \\
\hline \multicolumn{5}{|l|}{ BAP } \\
\hline \multirow[t]{2}{*}{1.0} & LF & - & - & + \\
\hline & IN & - & - & + \\
\hline \multirow[t]{2}{*}{1.5} & LF & - & - & + \\
\hline & IN & - & - & + \\
\hline \multirow[t]{2}{*}{2.0} & LF & - & - & + \\
\hline & IN & - & - & + \\
\hline \multicolumn{5}{|l|}{$\mathrm{BAP}+\mathrm{NAA}$} \\
\hline \multirow[t]{2}{*}{$1.0+0.1$} & LF & 70 & $6.5 \pm 0.60$ & + \\
\hline & IN & 70 & $6.2 \pm 0.37$ & + \\
\hline \multirow[t]{2}{*}{$1.0+0.2$} & LF & 45 & $4.5 \pm 0.40$ & ++ \\
\hline & IN & 45 & $3.8 \pm 0.20$ & ++ \\
\hline \multirow[t]{2}{*}{$1.0+0.5$} & LF & - & - & +++ \\
\hline & IN & 20 & $1.6 \pm 0.10$ & ++ \\
\hline \multirow[t]{2}{*}{$1.5+0.1$} & LF & 90 & $8.1 \pm 0.30$ & + \\
\hline & IN & 90 & $10.2 \pm 0.40$ & + \\
\hline \multirow[t]{2}{*}{$1.5+0.2$} & LF & 75 & $5.2 \pm 0.60$ & ++ \\
\hline & IN & 75 & $5.1 \pm 0.09$ & ++ \\
\hline \multirow[t]{2}{*}{$1.5+0.5$} & LF & 40 & $4.0 \pm 0.50$ & ++ \\
\hline & IN & 45 & $2.3 \pm 0.50$ & ++ \\
\hline \multirow[t]{2}{*}{$2.0+0.1$} & LF & 35 & $4.7 \pm 0.30$ & ++ \\
\hline & IN & 60 & $3.7 \pm 0.33$ & ++ \\
\hline \multirow[t]{2}{*}{$2.0+0.2$} & LF & - & - & +++ \\
\hline & IN & 20 & $1.5 \pm 0.51$ & ++ \\
\hline \multirow[t]{2}{*}{$2.0+0.5$} & LF & - & - & +++ \\
\hline & IN & - & - & +++ \\
\hline$B A P+I B A$ & & & & \\
\hline $1.0+0.1$ & LF & 50 & $5.1 \pm 0.50$ & + \\
\hline & IN & 50 & $3.7 \pm 0.10$ & + \\
\hline $1.0+0.2$ & LF & 35 & $3.4 \pm 0.20$ & ++ \\
\hline & IN & 40 & $2.4 \pm 0.20$ & ++ \\
\hline $1.0+0.5$ & LF & - & - & +++ \\
\hline & IN & - & - & +++ \\
\hline $1.5+0.1$ & LF & 75 & $6.1 \pm 0.70$ & + \\
\hline & IN & 70 & $4.3 \pm 0.10$ & + \\
\hline $1.5+0.2$ & LF & 55 & $5.0 \pm 0.15$ & ++ \\
\hline & IN & 50 & $3.0 \pm 0.15$ & ++ \\
\hline $1.5+0.5$ & LF & 30 & $4.0 \pm 0.50$ & ++ \\
\hline & IN & 30 & $2.3 \pm 0.30$ & ++ \\
\hline $2.0+0.1$ & LF & 25 & $2.1 \pm 0.10$ & ++ \\
\hline & IN & 40 & $2.1 \pm 0.16$ & ++ \\
\hline $2.0+0.2$ & LF & - & - & +++ \\
\hline & IN & - & - & +++ \\
\hline $2.0+0.5$ & LF & - & - & +++ \\
\hline & IN & - & - & +++ \\
\hline BAP + IAA & & & & \\
\hline $1.0+0.1$ & LF & 45 & $4.3 \pm 0.40$ & ++ \\
\hline & IN & 40 & $2.7 \pm 0.30$ & ++ \\
\hline $1.0+0.2$ & LF & 25 & $2.5 \pm 0.20$ & ++ \\
\hline & IN & 20 & $1.7 \pm 0.20$ & ++ \\
\hline $1.0+0.5$ & LF & - & - & +++ \\
\hline & IN & - & - & +++ \\
\hline $1.5+0.1$ & LF & 60 & $4.6 \pm 0.40$ & + \\
\hline & IN & 50 & $3.6 \pm 0.17$ & + \\
\hline $1.5+0.2$ & LF & 40 & $3.1 \pm 0.20$ & ++ \\
\hline & IN & 40 & $2.3 \pm 0.10$ & ++ \\
\hline $1.5+0.5$ & LF & 25 & $2.3 \pm 0.30$ & ++ \\
\hline & IN & 25 & $1.6 \pm 0.50$ & ++ \\
\hline $2.0+0.1$ & LF & 15 & $1.4 \pm 0.10$ & + \\
\hline & IN & 40 & $1.9 \pm 0.10$ & + \\
\hline $2.0+0.2$ & LF & - & - & +++ \\
\hline & IN & - & - & +++ \\
\hline $2.0+0.5$ & LF & - & - & +++ \\
\hline & IN & - & - & +++ \\
\hline
\end{tabular}


Table 2: (Continued)

\begin{tabular}{|c|c|c|c|c|}
\hline Growth regulators $(\mathrm{mg} / \mathrm{L})$ & Explant types & $\begin{array}{c}\text { Frequency of } \\
\text { Regeneration (\%) }\end{array}$ & $\begin{array}{l}\text { No. of total shoots per } \\
\text { culture }(\bar{X} \pm S . E .)\end{array}$ & Basal callus formation \\
\hline \multicolumn{5}{|l|}{$B A P+2-4-D$} \\
\hline \multirow{2}{*}{$1.0+0.1$} & LF & 40 & $2.7 \pm 0.20$ & + \\
\hline & IN & 40 & $2.3 \pm 0.10$ & + \\
\hline \multirow[t]{2}{*}{$1.0+0.2$} & LF & 20 & $2.1 \pm 0.30$ & ++ \\
\hline & IN & 15 & $1.3 \pm 0.30$ & ++ \\
\hline \multirow[t]{2}{*}{$1.0+0.5$} & LF & - & - & +++ \\
\hline & IN & - & - & +++ \\
\hline \multirow[t]{2}{*}{$1.5+0.1$} & LF & 50 & $3.1 \pm 0.20$ & + \\
\hline & IN & 45 & $3.3 \pm 0.10$ & + \\
\hline \multirow[t]{2}{*}{$1.5+0.2$} & LF & 30 & $2.3 \pm 0.20$ & ++ \\
\hline & IN & 25 & $2.0 \pm 0.20$ & ++ \\
\hline \multirow[t]{2}{*}{$1.5+0.5$} & LF & 15 & $1.4 \pm 0.39$ & ++ \\
\hline & IN & 15 & $1.1 \pm 0.39$ & ++ \\
\hline \multirow[t]{2}{*}{$2.0+0.1$} & LF & 25 & $1.1 \pm 0.10$ & ++ \\
\hline & IN & 25 & $1.6 \pm 0.10$ & ++ \\
\hline \multirow[t]{2}{*}{$2.0+0.2$} & LF & - & - & +++ \\
\hline & IN & - & - & +++ \\
\hline \multirow[t]{2}{*}{$2.0+0.5$} & LF & - & - & +++ \\
\hline & IN & - & - & +++ \\
\hline
\end{tabular}

$\mathrm{LF}=$ Leaf; $\mathrm{IN}=$ Internode; $(-)$ represents no response; $(+)$ indicates minor callusing; $(++)$ represents noticeable callusing; $(+++)$ represents abundant callusing

Table 3: Effect of different concentration of auxins on adventitious root formation from the in vitro grown micro-shoots cultured on full strength (MS) and half strength (MSS $)$ of MS medium

\begin{tabular}{|c|c|c|c|c|c|}
\hline Types of auxin & Medium strength & $\begin{array}{l}\text { Response of micro } \\
\text { shoots rooted (\%) }\end{array}$ & $\begin{array}{l}\text { Number of root per micro } \\
\text { shoots }(\overline{\mathrm{X}} \pm \text { S.E. })\end{array}$ & $\begin{array}{l}\text { Average length of the } \\
\operatorname{root}(\mathrm{cm})(\bar{X} \pm S . E .)\end{array}$ & $\begin{array}{l}\text { Callus formation } \\
\text { at the cutting base }\end{array}$ \\
\hline \multirow[t]{2}{*}{ Control } & MS & 60 & $4.2 \pm 0.70$ & $2.3 \pm 0.40$ & - \\
\hline & \multicolumn{4}{|c|}{ IBA } & - \\
\hline \multirow[t]{2}{*}{0.1} & MS & 90 & $6.2 \pm 0.37$ & $2.3 \pm 0.10$ & - \\
\hline & $\mathrm{MSS}_{1}$ & 95 & $6.8 \pm 0.10$ & $2.8 \pm 0.20$ & - \\
\hline \multirow[t]{2}{*}{0.2} & $\mathrm{MS}^{1}$ & 75 & $4.5 \pm 0.20$ & $1.8 \pm 0.20$ & + \\
\hline & $\mathrm{MSS}_{1}$ & 80 & $4.9 \pm 0.20$ & $2.1 \pm 0.10$ & + \\
\hline \multirow[t]{2}{*}{0.1} & MS & 85 & $5.1 \pm 0.30$ & $2.0 \pm 0.10$ & - \\
\hline & $\mathrm{MSS}_{1}$ & 90 & $5.5 \pm 0.40$ & $2.4 \pm 0.25$ & - \\
\hline \multirow[t]{2}{*}{0.2} & $\mathrm{MS}^{1}$ & 70 & $3.8 \pm 0.10$ & $1.6 \pm 0.51$ & + \\
\hline & $\mathrm{MSS}_{1}$ & 70 & $4.1 \pm 0.10$ & $1.8 \pm 0.51$ & + \\
\hline \multicolumn{6}{|l|}{ IAA } \\
\hline \multirow{2}{*}{0.1} & MS & 65 & $4.0 \pm 0.30$ & $1.8 \pm 0.40$ & - \\
\hline & $\begin{array}{l}\mathrm{MSS}_{1} \\
\mathrm{MS}_{1}\end{array}$ & $\begin{array}{l}70 \\
55\end{array}$ & $\begin{array}{l}5.1 \pm 0.30 \\
2.3 \pm 0.10\end{array}$ & $2.1 \pm 0.50$ & - \\
\hline 0.2 & $\mathrm{MSS}_{1}$ & 60 & $3.7 \pm 0.10$ & $\begin{array}{l}1.3 \pm 0.10 \\
1.6 \pm 0.10\end{array}$ & - \\
\hline
\end{tabular}

(-) represents no response; $(+)$ indicates minor callusing

explants without any contamination risk and any negative effect on bioresources, along with the potentiality for genetic transformation (Chaudhuri et al., 2008).

Hence, for the in vitro grown explant, the nodal segment was excised from immature field plants which sterilized with $0.1 \%$ $\mathrm{HgCl}_{2}$ for 6 minutes provide nearly $90 \%$ survived explants whereas 7 and 8 minutes cause the decease of cells 5 minutes showed contamination rate of $55 \%$ and develop axillary shoots. The nodal segment produces the highest rate (80\%) and number $(4.0 \pm 0.37)$ of shoots per culture at $1.5 \mathrm{mg} / \mathrm{L}$ BAP. Kn possessed a lower response rate than BAP and BAP, NAA combination. A Similar observation was reported by Shekhawat et al., (2014). Although, $0.5 \mathrm{mg} / \mathrm{L} \mathrm{BAP}$ and $0.5 \mathrm{mg} / \mathrm{L} \mathrm{NAA} \mathrm{had} \mathrm{not} \mathrm{produced}$ any shoots rather than profound callus. Despite this, $1.5 \mathrm{mg} / \mathrm{L}$
BAP combine with $0.1 \mathrm{mg} / \mathrm{L}$ NAA was found effective as $80 \%$ explants regenerated shoots with a length of $5.4 \pm 0.32 \mathrm{~cm}$. Sarker et al. (2009) reported that $1.5 \mathrm{mg} / \mathrm{L} \mathrm{BAP}$ and $0.5 \mathrm{mg} / \mathrm{L} \mathrm{NAA}$ as the most effective combination for shoot development which is in disagreement with the current study as the combination form noticeable callus. Thiripurasundari and Rao (2012) also reported of callus formation at MS medium with $1.5 \mathrm{mg} / \mathrm{L}$ BAP and $0.1 \mathrm{mg} / \mathrm{L}$ NAA. So, MS fortified with $1.5 \mathrm{mg} / \mathrm{L}$ BAP was efficacious to produce higher shoots since BAP might be easily metabolized by plant tissues. Conversely, $1.5 \mathrm{mg} / \mathrm{L}$ BAP combine with $0.1 \mathrm{mg} / \mathrm{LNAA}$ was potent for higher shoot length. Kashem and Rahman (2018) found a 100\% regeneration rate in Cocconia grandis, whereas Patel and Ishnava (2015) reported the length of shoot was $5.9 \pm 1.0 \mathrm{~cm}$ in the combine BAP and NAA PGRs supplement. 


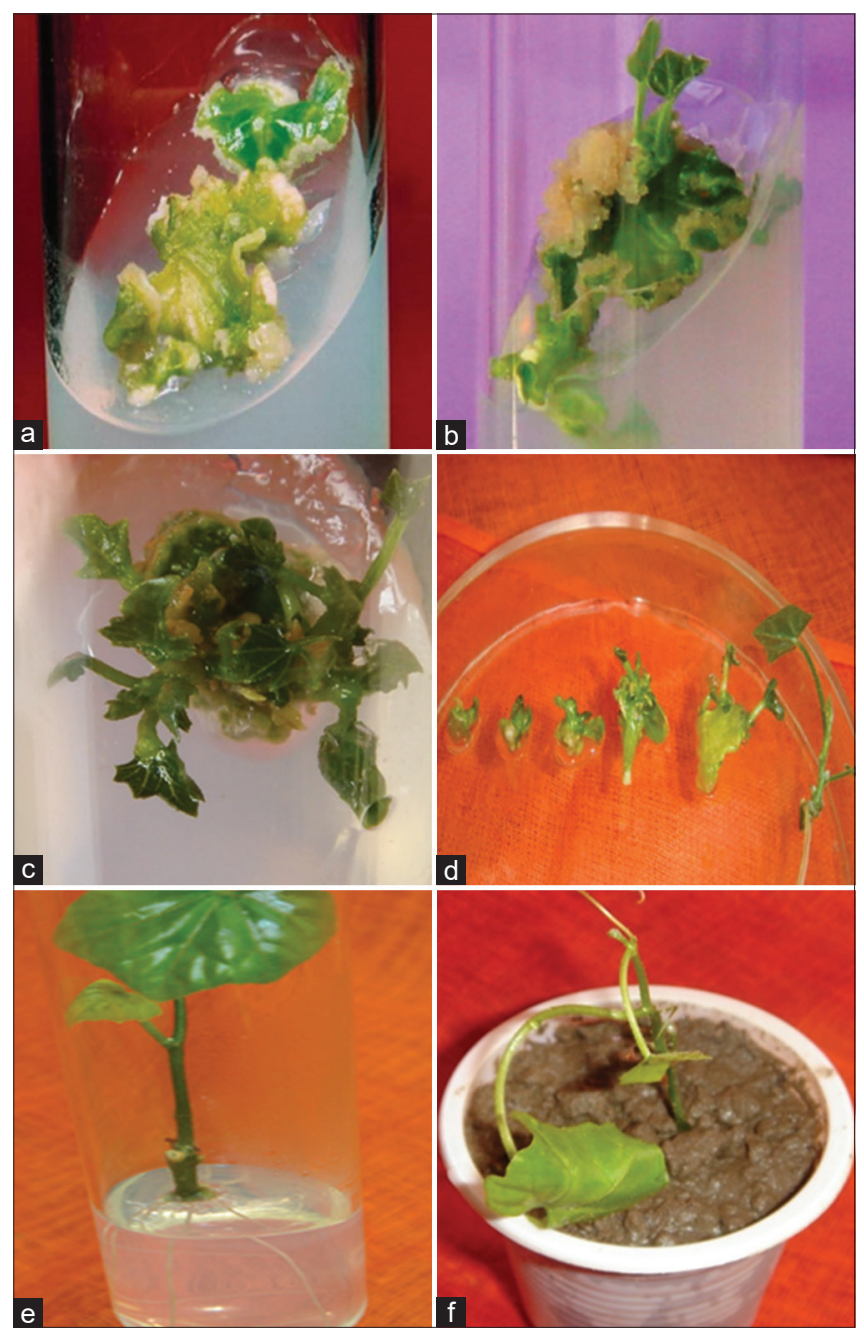

Figure 1: Direct organogenesis of Coccinia cordifolia (L.) Cogn. (a: leaf; b-c: direct shoot regeneration in full-strength MS medium supplemented with $1.5 \mathrm{mg} / \mathrm{L}$ BAP and $0.1 \mathrm{mg} / \mathrm{L}$ NAA from explants; d: proliferated shoots; e: in vitro root formation in half strength MS medium supplemented with $0.1 \mathrm{mg} / \mathrm{L}$ IBA; f: acclimatized plant)

Generally, every single cell can regenerate a whole eukaryotic species known as totipotency (Condic, 2014). This totipotency of a cell activates with cytokinin that works as a signal molecule, but for direct organogenesis, cytokinin activates the preexisting machinery of a somatic (leaf, internode, cotyledon) cells (Agarwal, 2015). Shoot proliferation from explant is also triggered by cytokinin, which stimulates the meristematic cells at the tip of the explants. However, C. cordifolia (L.) Cogn. couldn't regenerate any buds at the only BAP treatment in the current study (Table 2). In contrast, BAP with auxin in combination proliferate shoots as exogenous auxin might activate the cytokinin signaling pathway for the production of endogenous cytokinins that results in shoots induction (Pemisova et al., 2009) and auxin also animated the cell division, cell elongation, reactivation of differentiated cells, additional vascular tissue development and rein the formation of a lateral organ (Arciniega-Carreón et al., 2017).
Among all the combinations, $1.5 \mathrm{mg} / \mathrm{L}$ BAP and $0.1 \mathrm{mg} / \mathrm{L} \mathrm{NAA}$ supplemented in MS medium showed organogenic potentiality for both the explant and BAP with 2,4-D supplemented medium showed the lowest response rate. While higher concentrated BAP and auxin amended medium have an inhibitory impact on shoot induction as those combinations triggered the dedifferentiation of cells and form callus (Table 2). Notwithstanding, Josekutty et al. (1993) examined direct organogenesis from leaf and nodal segment of Coccinia indica at the PGR combination of $2.5 \mathrm{mg} / \mathrm{L}$ BAP, $0.5 \mathrm{mg} / \mathrm{L} \mathrm{Kn}$ and $0.1 \mathrm{mg} / \mathrm{L}$ IBA. A different outcome was found and was reported by Borah et al. (2019), as 90\% internode explant responded at $2.5 \mathrm{mg} / \mathrm{L} \mathrm{BAP}$ and $1.0 \mathrm{mg} / \mathrm{L} \mathrm{Kn}$ fortified MS medium and maximal bud regeneration was reported for MS medium with $1.5 \mathrm{mg} / \mathrm{L}$ BAP and $0.5 \mathrm{mg} / \mathrm{L} \mathrm{Kn}$ combination by Ghanthikumar et al. (2013).

Internode explant although having same regeneration rate, produced the most number $(10.20 \pm 0.40)$ of shoots in a single culture. Relatively mature and more vascular internodes' tissue than leaf might be responsible for the higher shoots regeneration (Dhital et al., 2011). Moreover, internodes might hold ample cytokinin during the incision to develop adventitious shoot at the time of explant inoculation in medium (Lakshmi et al., 2013).

Rooting is essential for micro-shoots for the ultimate development as plant, where the root system uphold the water and balance the water loss through poorly functioning stomata of leaves (Ehsandar et al., 2013). Therefore, maximum root induction efficacy was found at $0.1 \mathrm{mg} / \mathrm{L} \mathrm{IBA}$ amended halfstrength MS medium as it almost 95\% micro-shoot regenerates roots (Table 3). The use of low salt MS medium for rooting in in vitro induced shoots is a very common practice for $\mathrm{C}$. cordifolia (L.) Cogn. as Roy et al. (2012) evaluated strong root induction of $82.4 \%$ at $0.5 \mathrm{mg} / \mathrm{L}$ IBA containing half-strength MS medium. Sekhawat et al. (2014) also reported the potentiality of half salt strength in root formation and observed the best result in $2.0 \mathrm{mg} / \mathrm{L} \mathrm{IBA}$. Sundari et al. (2011) also reported IBA as profound auxin for root formation as $100 \%$ formed root in $0.1 \mathrm{mg} / \mathrm{L}$ IBA contained MS medium. IBA supremacy for root induction has also been reported in many others species of cucurbitaceae (Khalekuzzaman et al., 2012; Arciniega-Carreon et al., 2017). IAA found lowest responsive for root introduction due to might be imbalance of exogenous and endogenous auxins (Ghanthikumar et al., 2013). $70 \%$ and 60\% Microcutting also produce root in control (hormone omitted) half and full strength MS medium, respectively. These phenomena proved that micro-shoots might not need the exogenous auxins source to obtain rooting, however lower root number $(4.2 \pm 0.70$ and $5.2 \pm 0.50)$ and length $(2.3 \pm 0.40 \mathrm{~cm}$ and $2.5 \pm 0.10 \mathrm{~cm})$ in full and half strength control MS medium than exogenous auxin supplemented mediums indicates the auxin treatment increased the root number and roots length along with rooting percentage and the synchronicity of rooting (de Klerk, 2002).

The well-developed rooted plantlets are transferred into the sand, soil, and compost (1:2:1) mixing cultivated medium to adapt the plantlets in an outside environment. For plant acclimitazation to ex vitro condition root length and number is 
very important to uptake the nutrients and water in C. cordifolia (L.) Cogn. plantlets (Sanavy \& Moeini, 2003). The planted plants acclimatized to ex vitro environment gradually after 15 days greenhouse condition and $80 \%$ of the plants survived in the condition after a month-long observation (Figure lf).

\section{CONCLUSION}

The findings of the study for in vitro establishment of C. cordifolia (L.) Cogn. have been standardized with shoots regeneration, multiplication, rooting formation, and acclimatization. With full-strength MS medium supplemented with $1.5 \mathrm{mg} / \mathrm{L}$ BAP alone and combined with $0.1 \mathrm{mg} / \mathrm{L} \mathrm{NAA}$ were found productive as regeneration rate and shoot number and length were maximum. Internode segments was found as paramount for in vitro direct organogenesis as $90 \%$ of explants regenerated, having $10.2 \pm 0.40$ shoots per culture at the MS medium supplemented with 1.5 BAP and 0.1 NAA. Further, the plant had an $80 \%$ survival rate at ex vitro condition after getting maximum roots at $0.1 \mathrm{mg} / \mathrm{L} \mathrm{IBA}$ in a half-strength MS medium. The findings obtained from the study provide a basis for initiation of any biotechnological applications and transgenic plant development by in vitro manipulation of Coccinia cordifolia (L.) Cogn. and to serve as a convenient and useful technique for the mass propagation of this medicinal plant.

\section{ACKNOWLEDGEMENT}

The authors acknowledge the chairman and the teachers of the Department of Botany for their continuous suggestions and feedbacks.

\section{REFERENCE}

Agarwal, M. (2015). Tissue culture of Momordica charantia L.: A review. Journal of Plant Sciences, 3(1-1), 24-32.

Alam, I., Sharmin, S. A., Mondal, S. C., Alam, J., Khalekuzzaman, M., Anisuzzaman, M., \& Alam, M. F. (2010a). In vitro micropropagation through cotyledonary node culture of castor bean (Ricinus communis L.). Australian Journal of Crop Science, 4(2), 81-84.

Alam, J., Alam, I., Sharmin, S. A., Rahman, M., Anisuzzaman, M., \& Alam, M. F. (2010b). Micropropagation and antimicrobial activity of Operculina turpethum (Syn. Ipomoea turpethum), an endangered medicinal Plant. Plant Omics, 3(2), 40-46.

Alam, M. F., Mondol, P. C., Roy, S. K., Anisuzzaman, M., Parvez, M. S., Ray, S. K., Mahzabin F., Tanny T. \& Alam, I. (2019). Determination of Apposite plant regeneration protocol for several cucurbits through direct and indirect organogenesis. Horticulture Biotechnology Research, 5, 4-13. https://doi.org/10.25081/hbr.2019.v5.5279

Arciniega-Carreón, I. Y., Oliver-Salvador, C., Ramírez-Sotelo, M. G., \& Salas, C. E. (2017). Efficient in vitro plant regeneration from internode explants of Ibervillea sonorae: an antidiabetic medicinal plant. HortScience, 52(7), 1000-1005. https://doi.org/10.21273/ HORTSCI11942-17

Borah, A. R., Anbumalarmathi, J., \& Sharmili, S. A. (2019). In vitro propagation of Coccinia indica (L.) Voigt. from internodal segments. Indian Journal of Agricultural Research, 53(2), 202-207.

Brown, D. C., \& Thorpe, T. A. (1986). Plant regeneration by organogenesis. Cell culture and somatic cell genetics of plants, 3, 49-65.

Chaudhuri, R. K., Pal, A., \& Jha, T. B. (2008). Conservation of Swertia chirata through direct shoot multiplication from leaf explants. Plant Biotechnology Reports, 2(3), 213-218. https://doi.org/10.1007/ s11816-008-0064-5

Condic, M. L. (2014). Totipotency: what it is and what it is not. Stem Cells and Development, 23(8), 796-812. https://doi.org/10.1089/

\section{Fscd.2013.0364}

Corredoira, E., Ballester, A., \& Vieitez, A. M. (2008). Thidiazuron-induced high-frequency plant regeneration from leaf explants of Paulownia tomentosa mature trees. Plant Cell, Tissue and Organ Culture, 95(2), 197-208. https://doi.org/10.1007/s11240-008-9433-6

De Klerk, G. J. (2002). Rooting of micropropagules. In Plant Roots (pp. 556570). CRC Press.

Dhital, S. P., Lim, H. T., \& Manandhar, H. K. (2011). Direct and Efficient plant regeneration from different explants sources of potato cultivars as influenced by plant growth regulators. Nepal Journal of Science and Technology, 12, 1-6. https://doi.org/10.3126/njst.v12i0.6471

Ehsandar, S., Majd, A., \& Choukan, R. (2013). Callus formation and regeneration of the first modified Iranian potato cultivar (Savalan). Advances in Crop Science, 3, 201.

Ghanthikumar S., Arulanandam L. J. P., \& Joseph H. L. (2013). Micropropagation of Coccinia indica Wight \& Arn.-A medicinal plant. Applied Bio Research, 18, 1-4.

Girish, C., Balakrishnan, S., Koner, B. C., Jayanthi, S., Rao, K. R., Rajesh, B., \& Pradhan, S. C. (2011). Evaluation of antiulcer activity of Coccinia grandis leaves. Research Journal of Pharmacology \& Pharmacodynamics, 3, 2011-2013.

Hussain, A., Wahab, S., Rizvi, A., \& Hussain, M. (2011). Macroscopical, anatomical and physio-chemical studies on leaves of Coccinia indica Wight \& Arn., growing wildly in eastern Uttar Pradesh region of India. Indian Journal of Natural Products and Resources, 2(1), 74-80.

Josekutty, P. C., Shah, S., \& Prathapasenan, G. (1993). Direct and indirect organogenesis in Coccinia indica. Journal of Horticultural Science, 68(1), 31-35. https://doi.org/10.1080/00221589.1993.115 16325

Kashem, M. A., \& Rahman, M. M. (2018). Micropropagation of Coccinia grandis (Linn.) Voigt. Through organogenesis. European Journal of Biotechnology and Bioscience, 6(6), 63-68.

Khalekuzzaman, M., Khatun, M., Rashid, M. H., Sheikh, M. I., Sharmin, S. A., \& Alam, I. (2012). Micropropagation of an elite F1 watermelon (Citrullus lanatus) hybrid from the shoot tip of field grown plants. Brazilian Archives of Biology and Technology, 55(3), 335-340. https:// doi.org/10.1590/S1516-89132012000300002

Koné, M., Koné, T., Kouakou, H. T., Konaté, S., \& Ochatt, S. (2013). Plant regeneration via direct shoot organogenesis from cotyledon explants of Bambara groundnut, Vigna subterranea (L.) Verdc. Biotechnology, Agronomy, Society and Environment, 17(4), 584-592.

Lakshmi, S. R., Benjamin, J. H. F., Kumar, T. S., Murthy, G. V. S., \& Rao, M. V. (2013). Organogenesis from in vitro-derived leaf and internode explants of Hoya wightii ssp. palniensis-a vulnerable species of Western Ghats. Brazilian Archives of Biology and Technology, 56(3), 421-430. https://doi.org/10.1590/S1516-89132013000300010

Murashige, T., \& Skoog, F. (1962) A revised medium for rapid growth and bioassays with tobacco tissue cultures. Physiologia Plantarum, 15, 473-497. https://doi.org/10.1111/j.1399-3054.1962.tb08052.x

Patel, A. R., \& Ishnava, K. B. (2015). In vitro shoot multiplication from nodal explants of Coccinia grandis (L.) Voigt. and it's antidiabetic and antioxidant activity. Asian Journal of Biological Sciences, 8(2), 57-71. https://doi.org/10.13140/RG.2.1.2917.9603

Pekamwar, S. S., Kalyankar, T. M., \& Kokate, S. S. (2013). Pharmacological activities of Coccinia grandis. Journal of Applied Pharmaceutical Science, 3(5), 114-119.

Pernisová, M., Klíma, P., Horák, J., Válková, M., Malbeck, J., Souček, P., Reichman, P., Hoyerová, K., Dubová, J., Friml, J. and Za, E., \& Hejátko, J. (2009). Cytokinins modulate auxin-induced organogenesis in plants via regulation of the auxin efflux. Proceedings of the National Academy of Sciences, 106(9), 3609-3614. https://doi.org/10.1073/ pnas.0811539106

Ramachandran, A., Prasath, R., \& Anand, A. (2014). The medical uses of Coccinia grandis L. Voigt: A review. International journal of pharmacognosy, 1(11), 681-690. https://doi.org/10.13040/ IJPSR.0975-8232.IJP.1(11).681-90

Roy, C. K., Munshia, J. L., Begum, N., Khatun, R., \& Hassanb, A. S. (2012). In vitro plant regeneration of Coccinea cordifolia (Linn.) Cogn., an anti-diabetic medicinal plant. Bangladesh Journal of Scientific and Industrial Research, 47(2), 187-190. https://doi.org/10.3329/bjsir. v47i2.11450

Sanavy, S. A. M. M., \& Moeini, M. J. (2003). Effects of different hormone combinations and planting beds on growth of single nodes and plantlets resulted from potato meristem culture. Plant Tissue 
Culture, 13(2), 145-150.

Sarker, P. F. M. S., Jahan, R., \& Rahmatullah, M. (2009). In vitro regeneration of Coccinia grandis (L.) Voigt., an indigenous medicinal plant of Bangladesh. African Journal of Traditional, Complementary and Alternative Medicines, 351-352.

Sharmin, S. A., Alam, M. J., Sheikh, M. M., Zaman, R., Khalekuzzaman, M., Mondal, S. C., Haque, M. A., Alam, M. F., \& Alam, I. (2013). Micropropagation and antimicrobial activity of Curcuma aromatica Salisb., a threatened aromatic medicinal plant. Turkish Journal of Biology, 37(6), 698-708. https://doi.org/10.3906/biy-1212-11

Shasthree, T., Ramakrishna, D., Imran, M. A., \& Chandrashekar, C. (2014). Adventitious shoot organogenesis and plant regeneration from leaf and cotyledon explants of Citrullus colocynthis. Journal of Herbs, Spices \& Medicinal Plants, 20(3), 235-244. https://doi.org/10.1080/1 0496475.2013 .860071

Shekhawat, M. S., Ravindran, C. P., \& Manokari, M. (2014). Developmental and hormonal regulation of direct shoots and roots regeneration in Coccinia indica L. International Journal of Natural Sciences Research, 2(7), 103-112.

Shibli, R. A., \& Smith, M. A. L. (1996). Direct shoot regeneration from Vaccinium pahalae (ohelo) and V. myrtillus (bilberry) leaf explants. HortScience, 31(7), 1225-1228. https://doi.org/10.21273/HORTSCI.31.7.1225

Sundari, U. T., Sherif, N. A., Benjamin, J. F., \& Rao, M. V. (2011). Rapid micropropagation via axillary bud proliferation of Coccinia grandis (L.) Voigt. from nodal segments. Plant Tissue Culture \& Biotechnology, 21(1), 75-82.

Thiripurasundari, U., \& Rao, M. V. (2012). Indirect organogenesis from nodal explants of Coccinia grandis (L.) Voigt. Indian Journal of Biotechnology, 11(3), 352-354.

Verma, V., Zinta, G., \& Kanwar, K. (2021). Optimization of efficient direct organogenesis protocol for Punica granatum L. cv. Kandhari Kabuli from mature leaf explants. In Vitro Cellular \& Developmental BiologyPlant, 57(1), 48-59. https://doi.org/10.1007/s11627-020-10111-x

Yang, X., Lü, J., da Silva, J. A. T., \& Ma, G. (2012). Somatic embryogenesis and shoot organogenesis from leaf explants of Primulina tabacum. Plant Cell, Tissue and Organ Culture, 109(2), 213-221. https://doi.org/10.1007/s11240-011-0087-4

Zakaria, D. M., Islam, M., Anisuzzaman, S. M., Kundu, S. K., Khan, M. S., \& Begum, A. A. (2011). Ethnomedicinal survey of medicinal plants used by folk medical practitioners in four different villages of Gazipur district, Bangladesh. Advance in Natural and Applied Sciences, 5(4), 392-399.

Pal, S. P., Alam, I., Anisuzzaman, M., Sarker, K. K., Sharmin, S. A., \& Alam, M. F. (2007). Indirect organogenesis in summer squash (Cucurbita pepo L.). Turkish Journal of Agriculture and Forestry, 31(1), 63-70. 